\title{
Coexistence Between Hodgkin's Lymphoma and Renal Cell Cancer: Case Report
}

\section{Hodgkin Lenfoma - Renal Hücreli Kanser Birlikteliği: Olgu Sunumu}

\author{
Mustafa Karabıçak, Hakan Türk, Özgür Çakmak, Cemal Selçuk İşoğlu, Hüseyin Tarhan, \\ Ferruh Zorlu
}

Tepecik Training and Research Hospital, Clinic of Urology, İmir, Turkey

\begin{abstract}
Renal cell cancer (RCC) is the most common kidney tumor and accounts for $3 \%$ of all adult cancers. Hodgkin's lymphoma ( $\mathrm{HL}$ ) is also constitutes less than $1 \%$ of all malignancies with the male predominance. The risk of secondary cancer increases during the treatment period of $\mathrm{HL}$ in 15 years of followup. We presented a case indicating co-occurence between $\mathrm{HL}$ and RCC and literature review about this rare coincidence.
\end{abstract}

\section{Key words}

Hodgkin's lymphoma (HL), Non-hodgkin's lymphoma (NHL), renal cell cancer

\section{ÖZET}

Renal Hücreli Kanser (RHK) en sık görülen böbrek tümörü olup yetişkinlerde görülen malignitelerin yaklaşık \%3'ünü oluşturur. Hodgkin lenfoma (HL) tüm kanserlerin \%1' inden daha az görülmekte olup erkeklerde görülme sıklığı daha fazladır. HL tedavisi alan hastalarda 15 yıl takip süresi sonunda ikincil solid kanser görülme oranında artış görülmektedir. Bu çalışmamızda eşzamanlı olarak böbrek tümörü ve hodgkin lenfoma birlikteliği gösteren bir olguyu literatür bilgileri eşliğinde inceledik.

\section{Anahtar Kelimeler}

Hodgkin lenfoma (HL), nonhodgkin lenfoma (NHL), renal hücreli kanser (RHK)

\section{Introduction}

RCC is the most common type of kidney cancer and accounts for 3\% of all adult cancers with the male predominance. In recent decades the incidence of RCC has been rising due to widespread using of imaging methods and also appears to be increased with cigarrete use and with obesity (1). HL accounts less than \%1 of all malignancies and it's incidence is higher in male. It's reported that patients with NonHodgkin's lymphoma (NHL) have higher risk of secondary malignancy when compared to normal population $(2,3)$. Coexisting between RCC and $\mathrm{HL}$ is more rare event than coexisting between RCC and NHL. To our knowledge there is only one report in literature indicating coexistence between RCC and HL (4). We presented a case indicating coexistence between $\mathrm{HL}$ and RCC and literature review about this rare coincidence.

\section{Case Presentation}

We present the case of a 61 year-old man with 15 pack year of smoking history who admitted to hospital with lumbar pain. He had a history of inguinal herniorrhaphy forty years ago. Physical examination findings were normal and the results of laboratory examinations were all in normal ranges except for mild anemia (hemoglobin:12.2 g/dL). During the initial evaluation ultrasonography revealed a solid mass in the right kidney and spleen. Solid mass in spleen which is compatible with lymphoma, left paraaortic lymph nodes with up to $3 \mathrm{~cm}$ in diameter and also $3 \mathrm{~cm}$ solid mass originating from middle pole and lateral border of the right kidney were detected with magnetic resonance imaging (MRI) (Figure 1, 2). No evidence of any pathology observed with neck and thorax computed tomography (CT) study. Positron emission tomography (PET/CT) revealed increased activity in the region of spleen and paraaortic lymph nodes. Splenectomy, partial nephrectomy and regional lymph node dissection were performed. The result of histopathologic examination revealed RCC (clear cell carcinoma, fuhrman grade 2) and Hodgkin's lymphoma (mix cellular type) and all margins were negative for cancer. After an uneventful postoperative period the patient received radiotherapy and four cyles chemoterapy with a protocol of doxorubicin, bleomycin, dacarbazine, vinblastine.

\section{Discussion}

Treatment associated second malignancies have been described in long term survivors of Hodgkin's lymphoma (HL). Patients who

\section{Correspondence}

Hakan Türk MD, Tepecik Training and Research Hospital, Clinic of Urology, İzmir, Turkey

Phone: +90 5555516885 E-mail: hkntrk000@hotmail.com

Journal of Urological Surgery. 
received $\mathrm{HL}$ treatment, the occurence risk of secondary solid cancer is $13 \%, 17 \%$ and $22 \%$ in 15, 20 and 25 years follow-up consequently $(5,6,7,8,9)$. Synchronous NHL and RCC was previously reported and $\mathrm{NHL}$ was considered as a risk factor for renal cell carcinoma (10). RCC as a secondary malignancy developed during the follow-up period of lymphoma was also reported in a study from Turkey including five NHL patients (11). The most common secondary cancers developing after NHL treatment are reported to be breast, lung and gastrointestinal cancers in order (12). Kidney cancer as a treatment associated second malignancy was reported in five NHL patients in a cohort study (12). Various theories were postulated for this co-incidence and it's suggested that immunosupression related to drugs used for NHL treatment such as cyclophosphamide, prednisolone, vinblastine and

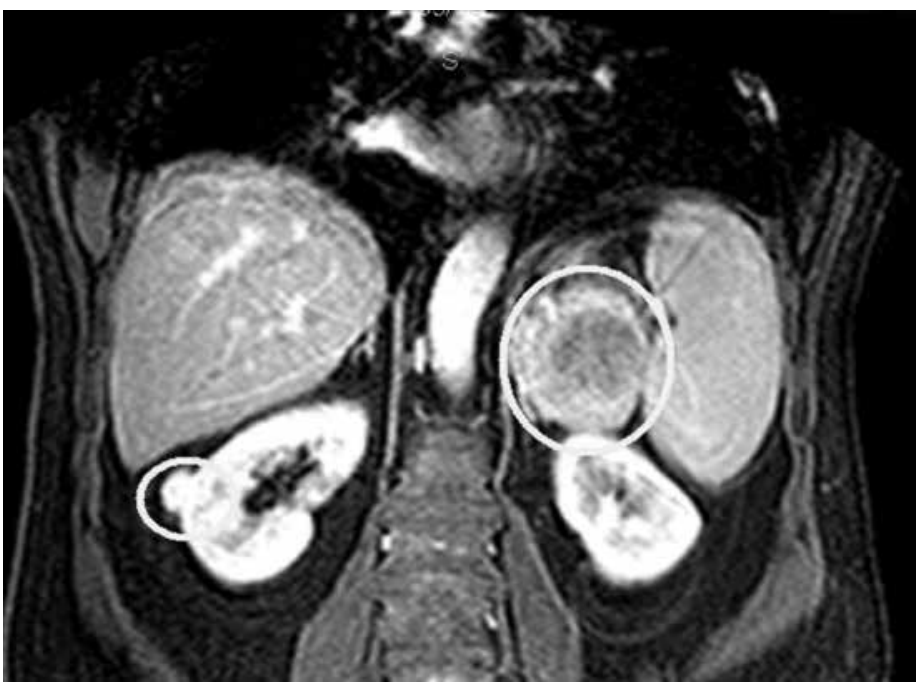

Figure 1. Two solid masses compatible with lymphoma in spleen, $3 \mathrm{~cm}$ solid mass in middle and lateral side of right kidney

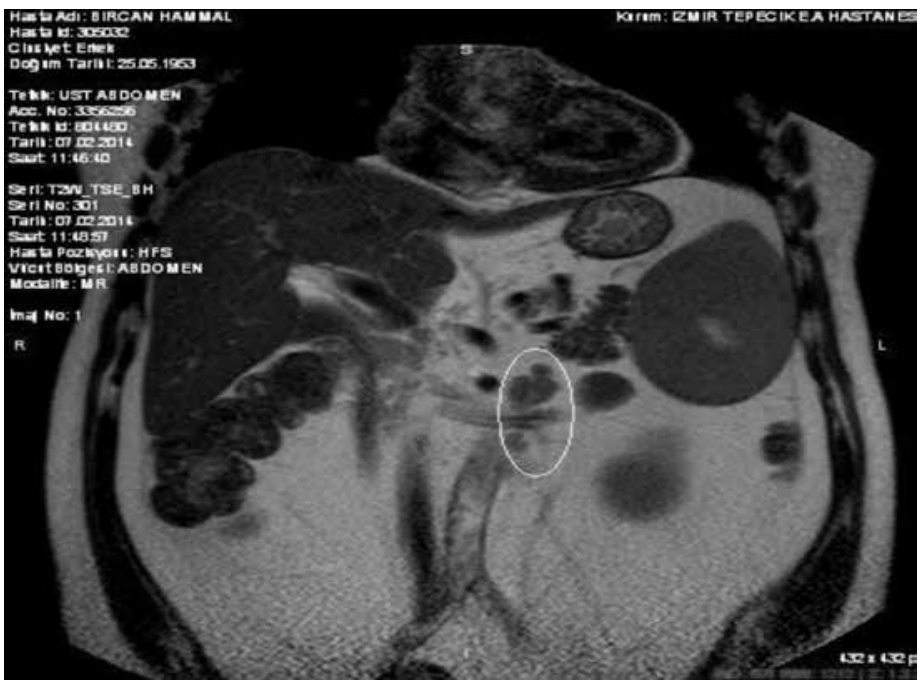

Figure 2. Pathological lymph nodes in left paraaortic space adriamycin may lead to RCC formation $(3,4)$. Immunodysregulation, genetic predisposition, chromosomal abnormalities and viral agents are some other factors accused of developing this association $(13,14,15)$. Despite all these theories postulated, it's not still clear the underlying mechanism of RCC developing in patients with lymphomas.

\section{Conclusions}

Secondary malignancies associated to treatment of $\mathrm{NHL}$ is well known entity. Although synochronous NHL and RCC were previously presented in some reports, scant data is present regarding the coexistence between $\mathrm{RCC}$ and $\mathrm{HL}$. The possibility of this coexistence should be kept in mind when evaluating these patients at diagnosis or during follow-up.

\section{References}

1. Ljungberg $B$, Campbell SC, Choi HY, et al: The epidemiology of renal cell carcinoma. Eur Urol 2011;60:615-21.

2. Travis LB, Curtis RE, Boice JD, et al: Second cancers following NonHodgkin's lymphoma. Cancer 1991;67:2002-9.

3. Travis $L B$, Curtis $R E$, Glimelius $B$, et al: Second cancers among long-term survivors of Non-Hodgkin's lymphoma. J Natl Cancer Inst 1993;85:19327.

4. Jimenez VH. Coexistence between renal cell cancer and Hodgkin's Iymphoma: a rare coincidence. BMC Urol 2006;6:10.

5. Swerdlow AJ, Higgins $C D$, Smith $P$, et al: Second cancer risk after chemotherapy for Hodgkin's lymphoma: a collaborative British cohort study. J Clin Oncol 2011;29:4096-104.

6. Dores GM, Metayer $\mathrm{C}$, Curtis RE, et al: Second malignant neoplasms among long-term survivors of Hodgkin's disease: a population-based evaluation over 25 years. J Clin Oncol 2002;20:3484-94.

7. Swerdlow AJ, Douglas AJ, Hudson GV, et al: Risk of second primary cancers after Hodgkin's disease by type of treatment: analysis of 2846 patients in the British National Lymphoma Investigation. BMJ 1992;304:1137-43.

8. O'Brien MM, Donaldson SS, Balise RR, et al: Second malignant neoplasms in survivors of pediatric Hodgkin's lymphoma treated with low-dose radiation and chemotherapy. J Clin Oncol 2010;28:1232-9.

9. Bonadonna G, Viviani S, Bonfante V, et al: Survival in Hodgkin's disease patients-report of 25 years of experience at the Milan Cancer Institute. Eur J Cancer 2005;41:998-1006.

10. Lossos C, Ferrell A, Duncan R, Lossos IS. Association between Non-hodgkin lymphoma and renal cell carcinoma. Leuk Lymphoma 2011;52:2254-61

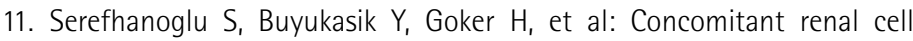
carcinoma and lymphoid malignancies: a case series of five patients and review of the literature. Med Oncol. 2010;27:55-8.

12. Swerdlow $A J$, Higgins $C D$, Smith $P$, et al: Second cancer risk after chemotherapy for Hodgkin's lymphoma: a collaborative British cohort study. J Clin Oncol 2011;29:4096-104.

13. Kunthur A, Wiernik PH, Dutcher JP. Renal parenchymal tumors and lymphoma in the same patient: Case series and review of the literature. Am J Hematol 2006;81:271-80.

14. Tihan T, Filippa D. Coexistence of renal cell carcinoma and malignant lymphoma: a causal relationship or coincidental occurrence. Cancer 1996;77:2325-31.

15. Aggisawa $K_{1}$ Ohno $Y$, Toba $K$, et al: Three cases of malignant lymphoma accompanied by renal cell carcinoma. Rinsho Ketsueki 2001;42:616-20. 